Chirurgia (2018) 113: 678-686

No. 5, September - October

Copyright@ Celsius

http://dx.doi.org/10.21614/chirurgia.113.5.678

\title{
Sarcopenia is a Predictive Factor for Postoperative Morbidity and Mortality in Patients Having Radical Gastrectomy for Cancer
}

\author{
Mircea Beuran ${ }^{1,2}$, Christina Tache ${ }^{1}$, Cezar Ciubotaru ${ }^{2}$, Mihaela Vartic ${ }^{3}$, Sorin Hostiuc ${ }^{4}$, Alina Prodan², \\ Massimo Sartelli ${ }^{5}$, Ewen A Griffiths ${ }^{6}$, Matthew Hernandez ${ }^{7}$, Ionut Negoi ${ }^{1,2}$ \\ 1"Carol Davila" University of Medicine and Pharmacy Bucharest, Romania \\ 2Department of General Surgery, Emergency Hospital of Bucharest, Romania \\ ${ }^{3}$ Intensive Care Unit, Emergency Hospital of Bucharest, Romania \\ ${ }^{4}$ Department of Legal Medicine and Bioethics, National Institute of Legal Medicine Mina Minovici, Romania \\ ${ }^{5}$ Department of Surgery, Macerata Hospital, Macerata, Italy. \\ ${ }^{6}$ University of Birmingham, Institute of Cancer and Genomic Sciences within the College of Medical and Dental Sciences, \\ Birmingham, United Kingdom. \\ 'Division of Trauma, Critical Care and General Surgery, Department of Surgery, Mayo Clinic, Rochester, MN, USA
}

Corresponding author:

Mircea Beuran, MD, Ph.D.

Professor of Surgery

"Carol Davila" University of Medicine and Pharmacy Bucharest, Romania

General Surgery Department Emergency Hospital of Bucharest No 8 Floreasca Street, Sector 1 , 014461, Bucharest, Romania,

E-mail: drbeuranmircea@yahoo.com

\section{Rezumat}

Sarcopenia este un factor predictiv pentru morbiditate și mortalitate postoperatorie la pacienții cu gastrectomie radicală pentru cancer

Introducere: Pacienții cu cancer gastric prezintă deseori deficiențe ale statusului nutrițional, 30\% până la 38\% dintre aceştia pierzând mai mult de $10 \%$ din greutatea corporală în ultimele 6 luni de boală. Sarcopenia reprezintă o scădere a funcției şi a masei musculare scheletale, de obicei fiind asociată cu procesul de îmbătrânire. Prevalența sarcopeniei raportată la pacienții cu cancer gastric ajunge până la 57.7\%. Deşi multe studii susțin impactul negativ al sarcopeniei la pacienți cu cancer gastric, există şi rezultate contradictorii prezentate în literatură. Obiectivul acestui studiu este de a investiga dacă sarcopenia se corelează cu o morbidate şi o mortalitate crescută, la pacienții cu cancer gastric rezecat.

Metodă: Am analizat restrospectiv toți pacienții ce au suferit gastrectomie radicală pentru adenocarcinom gastric în Spitalul Clinic de Urgență Bucureşti, în perioada Decembrie 2014 - Mai 2016. Am utilizat software-ul ImageJ pentru a măsura compoziția corporală a pacienților. Am indentificat ca şi punct de reper vertebra L3 şi am extras o singură secțiune de tomografie computerizată (TC). Rezultate: Am examinat 89 de pacienți care au avut gastrectomie radicală pentru cancer, însă 11 imagini TC nu au fost disponibile 
pentru analiză. Prin urmare, studiul a cuprins 78 de pacienți, dintre care 50 de bărbați (64.1\%) şi 28 de femei (35,9\%). Vârsta medie a pacientilor diagnosticați cu cancer gastric a fost 67.7 ani (între 22 şi 92 de ani). Localizarea tumorii primare a fost în treimea medie gastrică la 45 de pacienți (57.7\%), iar la 29 de pacienți (37.2\%) localizarea tumorii primare a fost în treimea distala gastrică. $\mathrm{Au}$ fost $72(92.3 \%)$ de pacienți externati în viață, iar $6(7.7 \%)$ au decedat în spital. $72.2 \%$ dintre pacienți erau sarcopenici, iar $27.78 \%$ non-sarcopenici. Valoarea medie a sarcopenie a fost de 43.77 . Cei mai mulți dintre pacienți au avut un index de masă musculară scheletală cuprins între 40.00 şi 45.00. Al doilea cel mai mare grup de pacienți au avut acest index cuprins între 35.00 şi 45.00 . Indexul de masă musculară scheletală se corelează cu vârsta pacienților. Rata de complicații şi rata de infecții de plagă se corelează deasemnea cu sarcopenia.

Concluzii: Sarcopenia prezintă o prevalență mare la pacienții operați pentru cancer gastric în România şi se corelează cu o morbiditate postoperatorie crescută. Odată cu creşterea tendinței pentru terapia neoadjuvantă, echipa multidisciplinară trebuie să evalueze şi să prevină sarcopenia.

Cuvinte cheie: sarcopenie, obezitate, gastrectomie, cancer gastric,moribiditate postoperatorie.

\begin{abstract}
Introduction: Patients with gastric cancer are frequently malnourished with $30 \%$ to $38 \%$ of them losing more than $10 \%$ of their weight in preceding six months. Sarcopenia represents a decrease in the skeletal muscle mass and function and is usually associated with the aging process. The prevalence of sarcopenia in patients with gastric cancer is reported to be as high as $57.7 \%$. Although many studies support the negative impact of sarcopenia in patients with gastric cancer, contradictory results are also present in the literature. The objective of this study is to investigate if sarcopenia is correlated with increased morbidity and mortality, in patients with gastric adenocarcinoma.

Methods: We studied retrospectively all patients having radical resection for gastric adenocarcinoma managed in the Emergency Hospital of Bucharest between December 2014 and May 2016. ImageJ software was used to measure the patients' body composition. We identified the L3 landmark and extracted that corresponding single cross-sectional image contained within a CT study.

Results: We reviewed 89 patients who had gastrectomy for cancer, but 11 Computed Tomography images were not available for analysis. Therefore, the study group consisted of 78 patients of which 50 were $(64.1 \%)$ males and $28(35.9 \%)$ females. The average age of patients diagnosed with gastric cancer was 67.7 years (range 22 to 92 years). The primary tumor location was the middle third of the stomach in 45 patients $(57.7 \%)$, and the second in the lower third of the stomach in 29 patients (37.2\%). There were $72(92.3 \%)$ patients who were living on discharge, with mortality in $6(7.7 \%)$ patients. $72.22 \%$ of patients are sarcopenic, and $27.78 \%$ were non-sarcopenic. The average sarcopenia value for both males and females is 43.77 . The greatest number of patients had a skeletal muscle index between 40.00 and 45.00 . The second greatest is between 35.00 and 40.00 . The muscular skeletal index correlated with the age of the patients. The overall complications rate and the surgical site infection rate correlated with the sarcopenia.

Conclusions: Sarcopenia is highly prevalent in patients having surgery for gastric cancer in Romania and correlates with increased postoperative morbidity. Especially with the increased trend for neoadjuvant therapy, the multidisciplinary team should evaluate and address sarcopenia through the perioperative period.
\end{abstract}

Key words: sarcopenia, obesity, gastrectomy, gastric cancer, postoperative morbidity 


\section{Introduction}

Although gastric cancer (GC) represents neoplasia with one of the most notable decreases in the age-standardized death rate between 2006 and 2016 (22.5\%) (1), it is still the fifth most frequent cancer and third cancer-related cause of death worldwide (2). Surgical resection represents the cornerstone of curative treatment $(3,4)$. Prognosis for , patients with non-resectable or metastatic disease is poor with the majority dying within 12 months even if they have palliative chemotherapy $(5,6)$. Despite ongoing progresses in surgical technique and perioperative care, radical gastrectomy is still associated with significant postoperative mortality $(1.8 \%-14.4 \%)$ and morbidity (16.7\% - 43\%) (7-10).

Patients with gastric cancer are frequently malnourished, with $30 \%$ to $38 \%$ of them losing more than $10 \%$ of their weight in preceding six months (11). Ongoing evidence supports that physical pre-habilitation and nutritional support before major abdominal surgery significantly improve the operative outcomes (12).

Sarcopenia represents a decrease in the skeletal muscle mass and function and is usually associated with the aging process (13). A decrease in the muscle mass is defined when a patient loses more than two standard deviations from the mean for healthy adults (14). Sarcopenia is correlated with a decrease in quality of life, injuries due to falls and increased mortality (15). The prevalence of sarcopenia in patients with gastric cancer was reported as high as $57.7 \%$ (16). In pathological conditions such as malignancies, the muscular body mass diminishes while the fatty tissue may remain the same or even increase. The sarcopenic obesity defines the loss of muscle mass associated with an increase in body fat; the current evidence supports an even worse impact on surgical outcomes in patients with gastric cancer (17). Although many studies support the negative impact of sarcopenia in patients with gastric cancer (18), contradictory results are also present in the literature (19) (see Fig. 1).

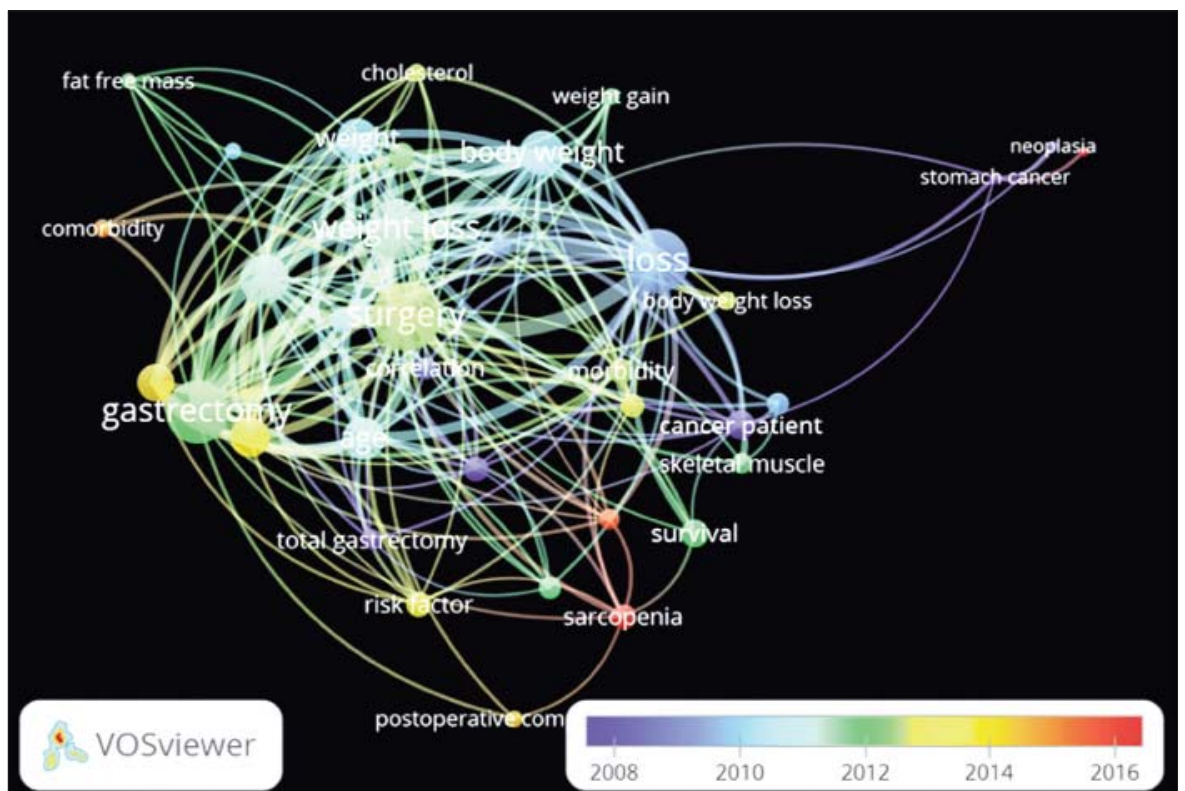

Figure 1. Text analysis of the titles and abstracts of the published literature (1793 papers), using in Web of Science all collections the following search strategy: TOPIC (gastrectomy) OR TOPIC: (gastric cancer) OR TOPIC: (stomach cancer) OR TOPIC: (gastric resection) OR TOPIC: (stomach resection) AND (sarcopenia) OR TOPIC: (muscle loss) OR TOPIC: (body composition). We can be observed the magnitude of relationships detailed in the medical literature between the surgical outcomes and nutritional parameters, in patients with gastrectomy. 
The objective of this study is to investigate if sarcopenia is correlated with increased morbidity and mortality, in patients with gastric adenocarcinoma.

\section{Methods}

\section{Patient Data}

We studied retrospectively all patients who had radical resection for gastric adenocarcinoma managed in the Emergency Hospital of Bucharest between December 2014 and May 2016. The data were collected from the discharge forms of the patient charts using the hospital's computerized database.

We extracted the following data: patients demographic data (age, gender, body mass index), clinical characteristics (reasons for admission, emergency presentation, type of complication, preexisting co-morbidities, American Society of Anesthesiologist class), blood samples (hemoglobin, albumin, total proteins, triglycerides, total cholesterol), radiological data (CT axial image on L3 vertebra), operative data (operation time, type of gastric resection, lymphadenectomy and reconstruction), pathology report (TNM staging, grading of differentiation), postoperative course (enteral and parenteral nutrition, length of stay, hospital mortality), and postoperative complications (20).

\section{Evaluation of the Body Composition and Sarcopenia}

To measure the patients' body composition, we used the Image $\mathrm{J}$ software. We identified the L3 landmark and extracted that corresponding single cross-sectional image contained within a CT study. In the L3 level CT axialsection, we distinguished the spinal vertebrae, small bowel loops, liver, kidney, visceral and subcutaneous adipose tissue, and seven muscle groups (the psoas, erector spinae, quadratus lumborum, external and internal obliques, transversus abdominis and rectus abdominis). We traced the abdominal perimeter to measure the waist circumference (see Fig. 2).

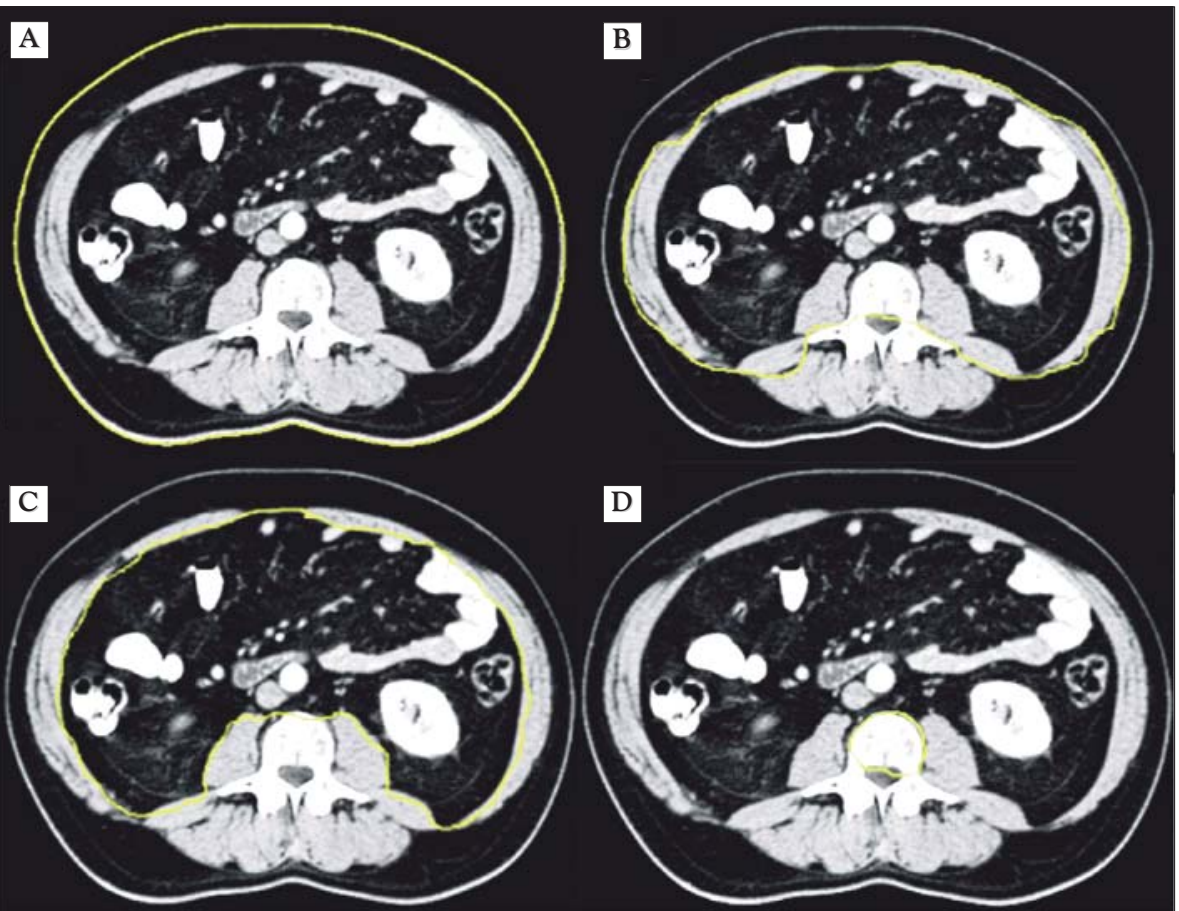

Figure 2. Measurement of the body composition: $A$ - measurement of the abdominal circumference; $\mathrm{B}$ - measurement of the abdominl muscles external perimeter; $C$ - measurement of the abdominal muscles internal perimeter; $D$ - measurement of the L3 vertebral body perimeter. 
After that, we measured the outer and inner musculature perimeters. These measurements were then compiled in a Microsoft Excel spreadsheet and the final calculations made (21). We used as sarcopenia definition a skeletal muscle index lower than $52.4 \mathrm{~cm}^{2} / \mathrm{m}^{2}$ in male and lower than $38.5 \mathrm{~cm}^{2} / \mathrm{m}^{2}$ in females.

\section{Statistical Analysis}

We reported all continuous variables with a normal distribution as mean and standard deviation. We used Kolmogorov-Smirnov test to verify the normal distribution of the data. For categorical data, we presented number and percentage. For univariate analysis, we used the independent T-test or Mann-Whitney $\mathrm{U}$ test, and Chi-square test or Fisher's exact test as appropriate.

For statistical analysis, we used SPSS version 24 for Mac. A two-tailed $\mathrm{P}$ of less than 0.05 was used to declare statistical significance.

\section{Results}

We reviewed 89 patients who had gastrectomy for cancer, but 11 Computed Tomography images were not available for analysis. Therefore, the study group consisted of 78 patients of which 50 were $(64.1 \%)$ males and 28 (35.9\%) females. The ratio between males and females was 1.78:1. The average age of patients diagnosed with gastric cancer was $67.7 \pm 12.7$ years (see Table 1).

The primary tumor location felled into the middle third category of the stomach which includes 45 patients (57.7\%), and the second in the lower third of the stomach 29 patients $(37.2 \%)$.

There were $47(66.2 \%)$ out of 78 patients with a history of cardiovascular disease. The second most common comorbidity was anemia with $35(49.3 \%)$ patients, and the third most common was gastrointestinal pathology with $34(47.9 \%)$ patients. Type 2 diabetes mellitus was present in $19(26.8 \%)$ patients.

The main complaint on admission was accelerated weight loss in $56(78.9 \%)$ and abdominal pain in $53(74.6 \%)$ of the patients. Vomiting was present in $45(63.4 \%)$ of patients and nausea in $43(60.6 \%)$ of patients. Loss of appetite was also widespread with 41 (57.7\%) of patients noting this phenomenon associated with their weight loss. Bleeding was noted in $27(38 \%)$ of patients, and there were 11 (15.5\%) patients who complained of asthenia.

The lowest albumin and total protein value during hospitalization were $2.930 .65 \mathrm{~g} / \mathrm{dl}$ and $5.281 .91 \mathrm{~g} / \mathrm{dl}$, respectively. The lowest cholesterol and triglycerides values were 137.9751.08 $\mathrm{mg} / \mathrm{dl}$ and $92.2237 .26 \mathrm{mg} / \mathrm{dl}$, respectively.

The type of resection was subtotal distal and total gastrectomy in $39(50 \%)$ and 37 $(47.4 \%)$ of patients, respectively. The most common reconstruction procedure was Rouxen-Y gastro- or eso-jejunostomy in 49 (62.82\%) of patients. The lymphadenectomy performed was a D1 and D1+ in $44(56.42 \%)$ patients and spleen and pancreas preserving D2 in 34 $(43.58 \%)$ cases.

The tumor stage was T3 in 28 (35.9\%), T4a

Table 1. Patients' demographic data

\begin{tabular}{lccc}
\hline & $\begin{array}{c}\text { Non-sarcopenic } \\
\text { (22 patients) }\end{array}$ & $\begin{array}{c}\text { Sarcopenic } \\
\text { (56 patients) }\end{array}$ & Statistical significance \\
\hline Age & 61.7 & 70.05 & $\mathrm{P}=0.034$ \\
Sex (M/F) & 1.83 & 1.76 & $\mathrm{P}=0.409$ \\
\hline TNM stage I & 4 & 2 & $\mathrm{P}=0.015$ \\
\hdashline II & 12 & 16 & \\
\hline III & 13 & 28 & \\
\hline IV & 4 & 9 & \\
\hline Total / Distal gastrectomy ratio & 0.81 & 0.99 & $\mathrm{P}=0.028$ \\
\hline
\end{tabular}


in $14(17.9 \%)$, T4b in $11(14.1 \%)$, T2a in 11 (14.1\%), T2b in $8(10.3 \%)$, T1a in $3(3.8 \%)$ and $\mathrm{T} 1 \mathrm{~b}$ in $3(3.8 \%)$ patients. The stage of lymph node involvement was $\mathrm{N} 2$ in $27(34.6 \%), \mathrm{N} 1$ in $16(20.5 \%)$, N0 in $12(15.4 \%)$ and N3 in 8 (10.3\%) patients. $65(83.3 \%)$ did not have any metastasis present. Poorly, moderately differentiated and well differentiated tumors were present in $48(61.5 \%), 24(30.8 \%)$ and $6(7.7 \%)$ of patients, respectively.

There were $72(92.3 \%)$ patients who were living on discharge, with mortality in $6(7.7 \%)$ patients. $72.22 \%$ of patients are sarcopenic, and $27.78 \%$ were non-sarcopenic. The average sarcopenia value for both males and females is 43.77. The greatest number of patients had a skeletal muscle index between 40.00 and 45.00. The second greatest is between 35.00 and 40.00. The muscular skeletal index correlated with the age of the patients (see Fig. 3). The overall complications rate and the surgical site infection rate correlated with the sarcopenia (see Table 2).

\section{Discussions}

We observed that sarcopenia correlates with increased overall complication and infection rate in patients with radical gastrectomy for cancer.

A prospective study of 158 patients with total gastrectomy and D2 lymphadenectomy

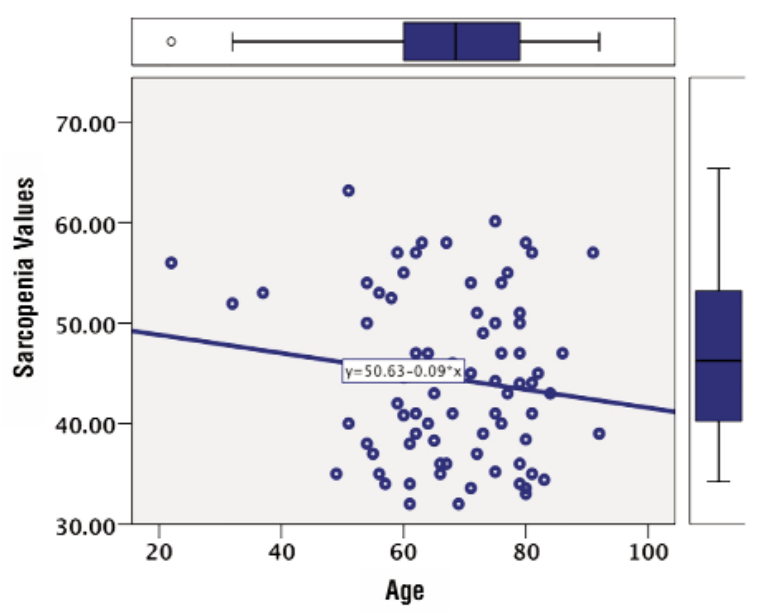

Figure 3. Correlation between skeletal muscular index and patients' age

showed a 30 -day complication rate of $27.2 \%$ (22). On multivariable analysis the sarcopenia $(\mathrm{OR}=3.084, \mathrm{P}=0.005)$ and tumor location at the cardia (OR $=2.347, \mathrm{P}=0.026)$ were independent predictors for postoperative complications (22). A study coming from China, which included 255 patients with gastrectomy showed that sarcopenia was present in $12.5 \%$ of cases (23). In multivariable analysis, the postoperative complications were correlated with sarcopenia $(\mathrm{P}<0.001)$ and diabetes $(\mathrm{P}=0.006)(23)$.

Shen et al. systematically reviewed the existing evidence about the impact of frailty

Table 2. Postoperative morbidities according to the skeletal muscular index.

\begin{tabular}{|c|c|c|c|c|c|}
\hline \multirow{3}{*}{$\begin{array}{l}\text { Outcomes } \\
\text { Overall complications }(P=0.002)\end{array}$} & \multirow{4}{*}{$\begin{array}{l}\text { No } \\
\text { Yes }\end{array}$} & \multicolumn{4}{|c|}{ Gender } \\
\hline & & \multicolumn{2}{|c|}{$\begin{array}{c}\text { Male } \\
\text { (skeletal muscle index, } \mathrm{cm}^{2} / \mathrm{m}^{2} \\
\text { mean } \pm \text { standard deviation) }\end{array}$} & \multicolumn{2}{|c|}{$\begin{array}{c}\text { Female } \\
\text { (skeletal muscle index, } \mathrm{cm}^{2} / \mathrm{m}^{2} \\
\text { mean } \pm \text { standard deviation) }\end{array}$} \\
\hline & & 55.90 & 7.61 & 41.72 & 4.47 \\
\hline & & 48.43 & 8.16 & 35.72 & 4.14 \\
\hline \multirow{2}{*}{ Surgical site infections $(P=0.048)$} & No & 48.17 & 7.68 & 38.27 & 4.56 \\
\hline & Yes & 41.00 & 5.73 & 36.00 & 6.98 \\
\hline \multirow[t]{2}{*}{ Thromboembolic events $(P=0.978)$} & No & 48.05 & 7.74 & 38.19 & 4.49 \\
\hline & Yes & 47.01 & 3.45 & 38.01 & 9.04 \\
\hline \multirow[t]{2}{*}{ Pulmonary complications $(P=0.689)$} & No & 47.78 & 7.68 & 38.55 & 4.46 \\
\hline & Yes & 54.05 & 5.66 & 33.50 & 0.71 \\
\hline \multirow[t]{2}{*}{ Cardiovascular complications $(P=0.329)$} & No & 48.05 & 7.90 & 38.37 & 4.46 \\
\hline & Yes & 47.67 & 2.08 & 33.00 & - \\
\hline
\end{tabular}


and sarcopenia in patients with gastrectomy older than 60 years (24). The authors found that sarcopenia was an independent risk factor for major postoperative complications $(\mathrm{OR}=3.12,95 \%$ CI 2.23 to 4.37$)(24) .28 .8 \%$ of 240 elderly patients with gastrectomy were sarcopenic, and had a significantly increased rate of postoperative complications (49.3\% versus $24.6 \%, \mathrm{P}<0.001)(25)$. Sato et al. found that low handgrip strength is a significant risk factor for increased morbidity after gastrectomy (26). Fukuda et al. revealed that sarcopenic patients had operatively a lower intake of calories and proteins (23.9 versus $27.9 \mathrm{kcal}$ per $\mathrm{kg}$ ideal weight / day, and 0.86 versus $1.04 \mathrm{~g}$ per $\mathrm{kg}$ of ideal weight / day), and presented a higher rate of severe postoperative complications $(57.1 \%$ versus $35.9 \%, \mathrm{P}=0.02)(27)$.

Huang et al. evaluated the impact of different stages of the sarcopenia on the postoperative outcomes after radical gastrectomy (26). From a total of 470 patients, $20.6 \%, 10 \%$, and $6.8 \%$ had presarcopenia, sarcopenia, and severe sarcopenia, respectively. Although all the three stages sarcopenia correlated with medical complications, only the severe stage was associated with an increased rate of surgical complications (26). In this study the 1 -year mortality was $13.9 \%$ (26). After the inclusion of sarcopenia, the predictive power of the area under the receiver operating characteristic curve for 1-year mortality increased from 0.835 to 0.868 (26). The current evidence supports that sarcopenia is not only associated with the perioperative outcomes, but also with poorer overall and disease-free survival in patients with stage II and III gastric cancer (18).

Contrary to the above mentioned evidence, an analysis of 152 patients from the Netherlands showed that $57.7 \%$ were sarcopenic, but this was not associated with increased in-hospital mortality $(\mathrm{P}=0.52)$, severe complications $(\mathrm{P}=1.00)$, and six-month mortality $(\mathrm{P}=0.069)(26)$.

Carneiro et al. reviewed 14 studies regarding the clinical consequences of sarcopenic obesity in cancer (28). The prevalence of sarcopenic obesity was $1-29 \%$ in populations of all body mass index categories, and $15-36 \%$ when only obese patients were included. The sarcopenic obesity was associated with higher surgical complication rate, physical disability and shorter survival (28). Analysis of 206 overweight or obese patients showed that 14 were sarcopenic (29). The sarcopenia was associated with higher postoperative complications, hospital costs, and 30day readmissions (29). Takeuchi et al. demonstrated that high visceral fat area is more useful than body mass index in predicting post-gastrectomy complications (26). A high visceral fat area was a predictor of anastomotic leakage (hazard ratio of $4.62,95 \%$ CI 1.02 to $21.02, \mathrm{P}=0.048$ ) and incisional surgical site infections (hazard ratio $4.32,95 \% \mathrm{CI} 1.18$ to $15.8, \mathrm{P}=0.02)(26)$.

Neoadjuvant chemotherapy (NAC) is recommended by NCCN guidelines in patients with locally advanced gastric cancer, being associated with better overall survival, diseasefree survival, and R0 resection rates (30-33). Mirkin et al. evaluated the change in sarcopenia score after NAC in 36 patients with surgical resection for advanced gastric cancer (34). $19 \%$ of patients were sarcopenic before neoadjuvant treatment, and an additional $14 \%$ developed sarcopenia during NAC. Sarcopenia was associated with increased postoperative complications $(\mathrm{P}=0.05)$ but not with higher mortality $(\mathrm{P}=0.23)$ or hospital stay $(P=0.74)(34)$. Tan et al. analyzed 89 patients with resections for esophago-gastric cancers, and found that sarcopenia $(\mathrm{OR}=2.95$, $\mathrm{P}=0.015)$ is associated with toxicity in patients under neoadjuvant chemotherapy (35). The sarcopenic patients presented a significant lower median survival (569 versus 1013 days, $\mathrm{P}=0.04$ ) (35).

The current evidence reveals two mechanisms through which cancer induces significant loss of muscle mass: a) cachexia, present in 50 $-80 \%$ of patients, secondary to muscle and adipose tissue degradation by systemic cytokines; b) sarcopenia, characterized by a decrease in muscle mass secondary advancing age, and present in $20-70 \%$ of patients $(36,37)$. However, it seems that preoperative prehabilitation is associated with better postoperative outcomes after major abdominal surgery (12, 38-42). 
A Cochrane systematic review which evaluates the effects of nutritional supplements administered preoperatively, found that immune-enhancing nutrition reduces the postoperative complication rate with a risk ratio (RR) of $0.67(95 \% \mathrm{CI} 0.53-0.4)$ and that parenteral nutrition reduced the complication rate with a RR of 0.67 (95\%CI $0.53-0.84)(36)$.

The results of the present study should be regarded with caution due to its limitations. First, there are inherent biases related to the retrospective nature of the collected data. Second, we reported a single-center, relatively small cohort of patients. Our hospital has an increased experience in managing patients with gastric cancer, and the results may not apply to other centers. Third, we evaluated the sarcopenia only though CT image analysis, without considering the muscle strength and performance.

\section{Conclusions}

Sarcopenia is highly prevalent in patients having surgery for gastric cancer in Romania and correlates with increased postoperative morbidity. Especially with the increased trend for neoadjuvant therapy, the multidisciplinary team should evaluate and address sarcopenia through the perioperative period. The preoperative prehabilitation, including nutritonal and physical interventions, seems to be associated with better postoperative outcomes.

\section{Conflicts of Interest}

Nothing to declare.

\section{Authors' Contributions}

All authors had equal contributed to this scientific paper.

\section{Reference}

1. GBD 2016 Causes of Death. Global, regional, and national age-sex specific mortality for 264 causes of death, 1980-2016: a systematic analysis for the Global Burden of Disease Study 2016.

2. Torre LA, Bray F, Siegel RL, Ferlay J, Lortet-Tieulent J, Jemal A. Global cancer statistics, 2012. CA Cancer J Clin. United States;
2015;65(2):87-108.

3. Hsu J-T, Lin C-J, Sung C-M, Yeh H-C, Chen T-H, Chen T-C, et al. Prognostic significance of the number of examined lymph nodes in node-negative gastric adenocarcinoma. Eur J Surg Oncol. England; 2013;39(11):1287-93.

4. Hsu J-T, Wang C-W, Le P-H, Wu R-C, Chen T-H, Chiang K-C, et al. Clinicopathological characteristics and outcomes in stage I-III mucinous gastric adenocarcinoma: a retrospective study at a single medical center. World J Surg Oncol. England; 2016;14:123.

5. Takeno A, Takiguchi S, Fujita J, Tamura S, Imamura H, Fujitani K, et al. Clinical outcome and indications for palliative gastrojejunostomy in unresectable advanced gastric cancer: multi-institutional retrospective analysis. Ann Surg Oncol. United States; 2013 ;20(11):3527-33.

6. Hsu J-T, Liao J-A, Chuang H-C, Chen T-D, Chen T-H, Kuo C-J, et al. Palliative gastrectomy is beneficial in selected cases of metastatic gastric cancer. BMC Palliat Care. 2017;16(1):19.

7. Budišin N, Budišin E, GoluboviC A. Early complications following total gastrectomy for gastric cancer. J Surg Oncol. 2001;77(1): 35-41.

8. McCulloch P. Ward J, Tekkis PP. Mortality and morbidity in gastrooesophageal cancer surgery: initial results of ASCOT multicentre prospective cohort study. BMJ. 2003:327(7425):1192-7.

9. Pedrazzani C, Marrelli D, Rampone B, De Stefano A, Corso G, Fotia $G$, et al. Postoperative complications and functional results after subtotal gastrectomy with Billroth II reconstruction for primary gastric cancer. Dig Dis Sci. United States; 2007;52(8):1757-63.

10. Sunil BJ, Seshadri RA, Mahajan V, Ellusami HR. Postoperative Morbidity and Mortality Following D2 Gastrectomy-an Audit of 456 Cases. Indian J Surg Oncol.2016;7(1):4-10.

11. Dewys WD, Begg C, Lavin PT, Band PR, Bennett JM, Bertino JR, et al. Prognostic effect of weight loss prior to chemotherapy in cancer patients. Eastern Cooperative Oncology Group. Am J Med. United States:1980;69(4):491-7.

12. West MA, Wischmeyer PE, Grocott MPW. Prehabilitation and Nutritional Support to Improve Perioperative Outcomes. Curr Anesthesiol Rep. 2017;7(4):340-9.

13. Santilli V, Bernetti A, Mangone M, Paoloni M. Clinical definition of sarcopenia. Clin Cases Miner Bone Metab. 2014;11(3):177-80.

14. Baumgartner RN, Koehler KM, Gallagher D, Romero L, Heymsfield $\mathrm{SB}$, Ross RR, et al. Epidemiology of sarcopenia among the elderly in New Mexico. Am J Epidemiol. 1998;147(8):755-63.

15. Janssen I. Influence of Sarcopenia on the Development of Physical Disability: The Cardiovascular Health Study. J Am Geriatr Soc. 2006; 54(1):56-62.

16. Tegels JJW, van Vugt JLA, Reisinger KW, Hulsewé KWE, Hoofwijk AGM, Derikx JPM, et al. Sarcopenia is highly prevalent in patients undergoing surgery for gastric cancer but not associated with worse outcomes. J Surg Oncol. 2015;112(4):403-7.

17. Nishigori T, Tsunoda S, Okabe H, Tanaka E, Hisamori S, Hosogi H, et al. Impact of Sarcopenic Obesity on Surgical Site Infection after Laparoscopic Total Gastrectomy. Ann Surg Oncol. 2016;23(Suppl 4):524-31.

18. Zhuang C-L, Huang D-D, Pang W-Y, Zhou C-J, Wang S-L, Lou N, et al. Sarcopenia is an Independent Predictor of Severe Postoperative Complications and Long-Term Survival After Radical Gastrectomy for Gastric Cancer. Medicine (Baltimore). 2016;95(13):e3164.

19. Fukuda $Y$, Yamamoto K, Hirao M, Nishikawa K, Nagatsuma $Y$, Nakayama T, et al. Sarcopenia is associated with severe postoperative complications in elderly gastric cancer patients undergoing gastrectomy. Gastric Cancer. 2016;19(3):986-93.

20. Gomez-Perez SL, Haus JM, Sheean P, Patel B, Mar W, Chaudhry V, et al. Measuring Abdominal Circumference and Skeletal Muscle From a Single Cross-Sectional Computed Tomography Image. J Parenter Enter Nutr. 2016;40(3):308-18.

21. Chen F-F, Zhang F-Y, Zhou X-Y, Shen X, Yu Z, Zhuang C-L. Role of frailty and nutritional status in predicting complications following total gastrectomy with D2 lymphadenectomy in patients with gastric cancer: a prospective study. Langenbeck's Arch Surg. 2016; 
401(6):813-22

22. Wang S-L, Zhuang C-L, Huang D-D, Pang W-Y, Lou N, Chen F-F, et al. Sarcopenia Adversely Impacts Postoperative Clinical Outcomes Following Gastrectomy in Patients with Gastric Cancer: A Prospective Study. Ann Surg Oncol. 2016;23(2):556-64.

23. Shen $Y$, Hao Q, Zhou J, Dong B. The impact of frailty and sarcopenia on postoperative outcomes in older patients undergoing gastrectomy surgery: a systematic review and meta-analysis. BMC Geriatr BioMed Central; 2017;17(1):188.

24. Carneiro IP, Mazurak VC, Prado CM. Clinical Implications of Sarcopenic Obesity in Cancer. Current Oncology Reports. Springer US; 2016. p. 62.

25. Lou N, Chi C-H, Chen X-D, Zhou C-J, Wang S-L, Zhuang C-L, et al. Sarcopenia in overweight and obese patients is a predictive factor for postoperative complication in gastric cancer: A prospective study. Eur J Surg Oncol. 2017;43(1):188-95.

26. Ychou M, Boige V, Pignon J-P, Conroy T, Bouché O, Lebreton G, et al. Perioperative Chemotherapy Compared With Surgery Alone for Resectable Gastroesophageal Adenocarcinoma: An FNCLCC and
FFCD Multicenter Phase III Trial. J Clin Oncol. 2011;29(13): 1715-21.

27. Cunningham D, Allum WH, Stenning SP, Thompson JN, Van de Velde CJH, Nicolson M, et al. Perioperative Chemotherapy versus Surgery Alone for Resectable Gastroesophageal Cancer. N Engl J Med. 2006;355(1):11-20.

28. NCCN. NCCN Clinical Practice Guidelines: Gastric Cancer Version 5. 2017. Available from: https://www.nccn.org/professionals/physician_gls/pdf/gastric.pdf

29. Schuhmacher C, Gretschel S, Lordick F, Reichardt P, Hohenberger W, Eisenberger CF, et al. Neoadjuvant Chemotherapy Compared With Surgery Alone for Locally Advanced Cancer of the Stomach and Cardia: European Organisation for Research and Treatment of Cancer Randomized Trial 40954. J Clin Oncol. 2010;28(35): $5210-8$.

30. Mirkin KA, Luke FE, Gangi A, Pimiento JM, Jeong D, Hollenbeak CS, et al. Sarcopenia related to neoadjuvant chemotherapy and perioperative outcomes in resected gastric cancer: a multiinstitutional analysis. J Gastrointest Oncol. 2017;8(3):589-95. 